\title{
Miocene basement exhumation in the Central Alps recorded by detrital garnet geochemistry in foreland basin deposits
}

\author{
Laura Stutenbecker ${ }^{1}$, Peter M. E. Tollan ${ }^{2}$, Andrea Madella ${ }^{3}$, and Pierre Lanari ${ }^{2}$ \\ ${ }^{1}$ Institute of Applied Geosciences, Technische Universität Darmstadt, Schnittspahnstr. 9, 64287 Darmstadt, Germany \\ ${ }^{2}$ Institute of Geological Sciences, University of Bern, Baltzerstrasse 1+3, 3012 Bern, Switzerland \\ ${ }^{3}$ Department of Geosciences, University of Tübingen, Wilhelmstr. 56, 72074 Tübingen, Germany
}

Correspondence: Laura Stutenbecker (stutenbecker@geo.tu-darmstadt.de)

Received: 4 June 2019 - Discussion started: 14 June 2019

Revised: 14 August 2019 - Accepted: 20 August 2019 - Published: 20 September 2019

\begin{abstract}
The Neogene evolution of the European Alps was characterized by the exhumation of crystalline basement, the so-called external crystalline massifs. Their exhumation presumably controlled the evolution of relief, distribution of drainage networks, and generation of sediment in the Central Alps. However, due to the absence of suitable proxies, the timing of their surficial exposure and thus the initiation of sediment supply from these areas are poorly constrained.

The northern Alpine foreland basin preserves the Oligocene to Miocene sedimentary record of tectonic and climatic adjustments in the hinterland. This contribution analyses the provenance of 25 to $14 \mathrm{Myr}$ old alluvial fan deposits by means of detrital garnet chemistry. Unusually grossularand spessartine-rich garnet is found (1) to be a unique proxy for identifying detritus from the external crystalline massifs and (2) to occur abundantly in ca. 14 Myr old deposits of the foreland basin. In contrast to previous assumptions, we therefore propose that the external massifs were already exposed to the surface ca. $14 \mathrm{Myr}$ ago.
\end{abstract}

\section{Introduction}

Tectonic processes drive the evolution of relief in mountain chains and consequently control the development of the drainage network, sediment supply, and deposition in the foreland basin. The Central European Alps and their northern foreland basin, formed through the collision of the European and the Adriatic continents since the Eocene (Schmid et al., 1996; Handy et al., 2010), are a classic example of such interactions (e.g. Schlunegger et al., 1998; Pfiffner et al., 2002; Vernon et al., 2008, 2009; Baran et al., 2014; Fox et al., 2015). The exhumation of large slices of mid-crustal rocks from the European plate, the so-called external crystalline massifs, occurred relatively late in the Alpine evolution, probably during the late Miocene, although the exact timing is not well constrained. The external crystalline massifs are today characterized by high relief, intense glaciation, and some of the highest denudation rates in the Alps (up to $1.4 \mathrm{~mm} \mathrm{yr}^{-1}$ ), which all contribute to their relevance as a sediment source (Kühni and Pfiffner, 2001; Wittmann et al., 2007; Stutenbecker et al., 2018). The exhumation is discussed as being related to crustal delamination in response to lithospheric mantle rollback (Herwegh et al., 2017), slab detachment (Fox et al., 2015), or erosional unloading (Champagnac et al., 2009), possibly due to increased precipitation rates in the Pliocene (Cederbom et al., 2004) or enhanced glacial erosion in the Pleistocene (Fox et al., 2015; Herman et al., 2013).

Peak metamorphism of lower to upper greenschist facies conditions occurred between 17 and $22 \mathrm{Ma}$ in all northern external crystalline massifs (Mont Blanc, Aar massifs, and the Gotthard nappe; Challandes et al., 2008; Rolland et al., 2008; Cenki-Tok et al., 2014; Nibourel et al., 2018). Their subsequent exhumation has been investigated using thermochronology (e.g. Schaer et al., 1975; Wagner et al., 1977; Michalski and Soom, 1990; Vernon et al., 2009; Glotzbach et al., 2010). Whereas some studies concluded that exhumation was episodic (e.g. Vernon et al., 2009), others suggest relatively constant exhumation rates of $0.5-0.7 \mathrm{~km} \mathrm{Myr}^{-1}$ since $14 \mathrm{Ma}$ (Michalski and Soom, 1990; Glotzbach et al., 2010). A focus in this debate concerns the late Neogene cooling and 
the onset of glaciation in the Pleistocene and their possible effect on the exhumation, erosion, and sediment accumulation rates (e.g. Kuhlemann et al., 2002; Herman et al., 2013; Schildgen et al., 2018). In contrast, the early Neogene exhumation history received comparably little attention. In particular, the timing of the first surficial exposure of the external massifs has never been constrained because estimates of their total thickness have not been established yet. In most geometric reconstructions (e.g. Pfiffner, 1986, 2017; Schmid et al., 2004), the contact between the crystalline basement and the overlying Mesozoic cover is assumed to be relatively flat, and the top of the crystalline basement is hypothesized to have been less than $1 \mathrm{~km}$ above the modern topography. Conversely, a new reconstruction of this tectonic contact allows for a substantially greater amount $(\sim 8 \mathrm{~km})$ of (now eroded) crystalline rock on top of the present-day topography (Nibourel et al., 2018).

This study aims to constrain the timing of exposure and thus the beginning of sediment supply from the external crystalline massifs, by determining the provenance of the foreland basin deposits. Sedimentary rocks preserved in the northern peripheral foreland basin of the Central Alps, the Swiss part of the Molasse basin, are a well-studied archive recording tectonic and climatic adjustments in the central orogen between ca. 32 and $14 \mathrm{Myr}$ ago (Schlunegger et al., 1993, 1996; Kempf et al., 1999; Spiegel et al., 2000; Kuhlemann and Kempf, 2002; von Eynatten, 2003; Schlunegger and Kissling, 2015). So far, the provenance of the Molasse deposits has been investigated using optical heavy mineral analysis, framework petrography, and both bulk and single-grain geochemical techniques, including epidote geochemistry and cooling ages derived from zircon fission track analysis and Ar-Ar dating of white mica (Spiegel et al., 2000, 2002; von Eynatten, 2003; von Eynatten and Wijbrans, 2003). No conclusive evidence for a contribution from the external crystalline massifs, however, has been found thus far, leading to the assumption that their exposure must postdate the youngest preserved (ca. $14 \mathrm{Myr}$ old) Molasse deposits (von Eynatten, 2003).

In this study, we use major element geochemistry of detrital garnet in Miocene deposits from the central part of the Swiss foreland basin. The great compositional variability displayed by garnet from different source rocks means that it is a useful provenance tracer in a variety of settings (Spear, 1994; Mange and Morton, 2007). Furthermore, it is a common heavy mineral in orogenic sediments and sedimentary rocks (Garzanti and Andò, 2007) and is relatively stable during transport and diagenesis (Morton and Hallsworth, 2007). In the Central Alps, detrital garnet has recently been shown to be a valuable provenance indicator, especially for distinguishing detritus supplied from the external crystalline massifs (Stutenbecker et al., 2017). We aim (1) to explore if detrital garnet geochemistry can help identifying additional provenance changes in the Miocene Molasse deposits that have gone unnoticed so far and (2) to test whether detritus from the external massifs is present in the younger Molasse deposits in order to give independent constraints on the timing of crystalline basement exhumation.

\subsection{Geological setting}

The Central Alps evolved through convergence between the European continental margin in the north and the Adriatic plate in the south (Schmid et al., 1996). The convergence started during the Late Cretaceous with the subduction of the Alpine Tethys Ocean below the Adriatic microplate (Froitzheim et al., 1996) and ceased during the Paleogene after the European continental lithosphere entered the subduction zone. These Cretaceous to early Neogene orogenic processes are reflected by the syn-orogenic deposition of deep-marine flysch units preserved throughout the Alps (e.g. Wildi, 1985; Winkler, 1996). Around $32 \mathrm{Myr}$ ago, the sedimentation style in the northern foreland basin changed from marine, flysch-like deposition to shallow marine and terrestrial sedimentation (Allen et al., 1991; Sinclair, 1997). This is thought to represent the transition to Molasse-type sedimentation in an overfilled basin and is discussed to be potentially related to a break-off of the European slab around the time of the Eocene-Oligocene boundary (e.g. Sinclair et al., 1991; Sinclair, 1997; Schlunegger and Kissling, 2015). Since this time, the northern foreland basin has become a major sink of orogenic detritus and an important sedimentary archive.

The sedimentary rocks in the Swiss part of the northern foreland basin are divided into four lithostratigraphic units that represent two shallowing- and coarsening-up megacycles (Schlunegger et al., 1998). The first cycle consists of the Rupelian Lower Marine Molasse and the Chattian and Aquitanian Lower Freshwater Molasse. The second megacycle comprises a transgressive facies of Burdigalian age (the Upper Marine Molasse) overlain by Langhian to Serravallian deposits of the Upper Freshwater Molasse. The depositional ages of these units were constrained using mammal biostratigraphy and magnetostratigraphy (Engesser, 1990; Schlunegger et al., 1996). Throughout the Oligocene and the Miocene, the proximal Molasse deposits are thought to have been formed through a series of large alluvial fans (Fig. 1) aligned along the Alpine thrust front (Schlunegger et al., 1993; Kuhlemann and Kempf, 2002). The more distal parts of the basin, on the other hand, were characterized by axial drainage directed towards the Paratethys in the eastnortheast (31-20 Ma) and the western Mediterranean Sea in the southwest (after 20 Ma) (Kuhlemann and Kempf, 2002). Whereas the more distal deposits could be significantly influenced by long-distance transport from the northeast or southwest, the alluvial fans are thought to carry a local provenance signal from the rocks exposed immediately south of each fan system due to their proximal nature. 


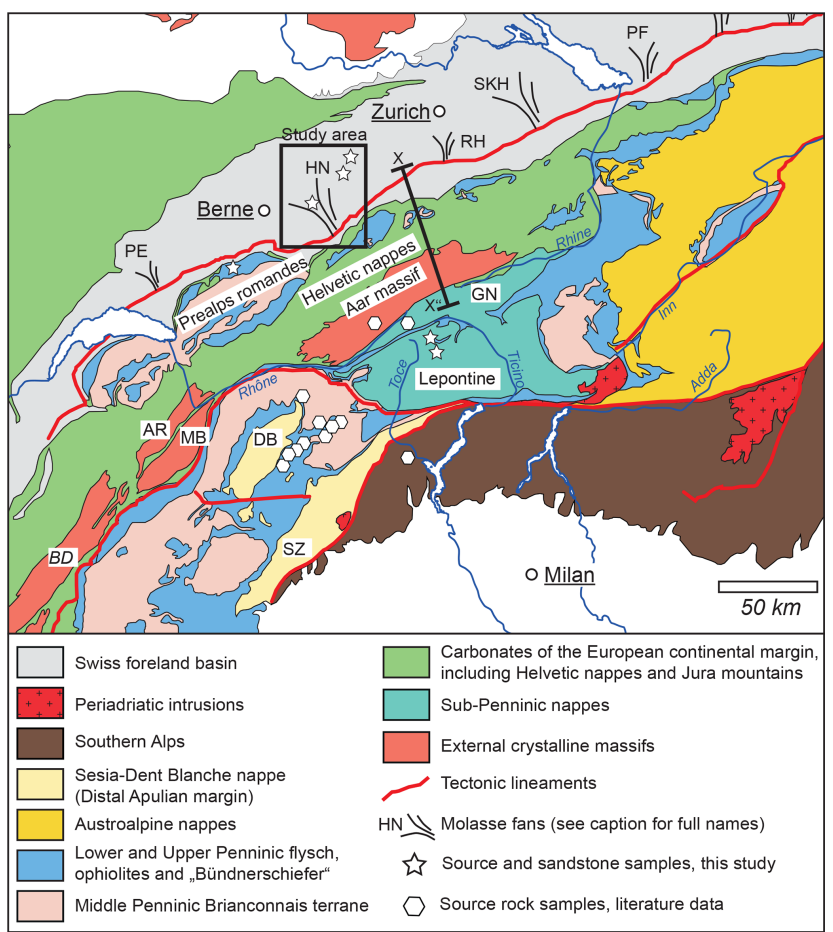

Figure 1. Simplified tectonic map of the Central Alps after Schmid et al. (2004) highlighting the location of alluvial fan deposits within the northern Alpine foreland basin as well as the most important source rock units in the hinterland. The Honegg-Napf fan, marked by the black rectangle, is located in the central part of the Swiss foreland basin (SFB). For cross section $X-X^{\prime \prime}$ see Fig. 7. Abbreviations used: AR - Aiguilles Rouges massif; BD - Belledonne massif; DB - Dent Blanche nappe; HN - Honegg-Napf fan; MB - Mont Blanc massif; GN - Gotthard nappe; PE - Pèlerin fan; PF - Pfänder fan; RH - Rigi-Höhronen fan; SKH - Speer-Kronberg-Hörnli fan; SZ - Sesia zone.

The hinterland of the central Swiss foreland basin comprises, from north to south, potential source rocks derived from the following tectonic units (Figs. 1, 2).

1. The Romandes Prealps; a stack of non-metamorphic and weakly metamorphosed sedimentary cover nappes (Mesozoic carbonate and Cretaceous-Eocene flysch), interpreted as the accretionary wedge of the Alpine Tethys, detached from its basement and thrust northwards onto the European units.

2. The Helvetic nappes; the non- or very low-grade metamorphic sedimentary cover sequence of the European continental margin (mostly Mesozoic carbonate).

3. The external crystalline massifs; lentoid-shaped autochthonous bodies of European continental crust that consist of a pre-Variscan polycyclic gneiss basement intruded by upper Carboniferous to Permian granitoid rocks and an overlying metasedimentary cover. They were buried within the Alpine nappe stack during the
Oligocene (Cenki-Tok et al., 2014), reaching greenschist facies peak-metamorphic conditions between 17 and $22 \mathrm{Myr}$ ago (Fig. 2a) and were exhumed during the Miocene. The Gotthard nappe, although not a "massif" sensu stricto because of its allochthonous nature, will be included in the term "external crystalline massifs" from here on because the timing and the rates of exhumation are comparable (Fig. 2b, Glotzbach et al., 2010).

4. The Lepontine dome; an allochthonous nappe stack of European Palaeozoic gneiss basement and its Mesozoic metasedimentary cover (Berger et al., 2005). Amphibolite facies peak metamorphism (Frey and Ferreiro Mählmann, 1999; Fig. 2a) in the Lepontine occurred diachronously at around 30-27 Myr ago in the south (Gebauer, 1999) and possibly as late as $19 \mathrm{Myr}$ ago in the north (Janots et al., 2009). Although the onset of exhumation of the Lepontine dome might have been equally diachronous, it is generally assumed to have occurred before $23 \mathrm{Myr}$ ago (Hurford, 1986).

5. The Penninic nappes, containing ophiolite of the Alpine Tethys as well as the continental crust of Briançonnais, a microcontinent located within the Alpine Tethys between the southern Piedmont-Ligurian ocean and the northern Valais trough (Schmid et al., 2004).

6. The Austroalpine nappes, containing the basement and sedimentary cover of the Adriatic plate with a Cretaceous ("Eoalpine", ca. 90-110 Ma) metamorphic peak of greenschist facies conditions (Schmid et al., 2004). The Austroalpine nappes were probably part of the nappe stack in the Central Alps prior to their erosion during the Oligocene and Miocene, although they are found exclusively in the Eastern Alps to the east of the Lepontine dome today.

7. The Sesia-Dent Blanche nappe, probably representing rifted segments of the basement and sedimentary cover of a distal part of the Adriatic plate (Froitzheim et al., 1996). In contrast to the Austroalpine nappes, the Sesia-Dent Blanche nappe was subducted and exposed to blueschist facies (Fig. 2a; Bousquet et al., 2012) and to eclogite facies metamorphism (e.g. Oberhänsli et al., 2004).

\subsection{Compositional trends in the Honegg-Napf fan}

The Central Alps are generally regarded as the major sediment source of all proximal Molasse basin deposits, and compositional changes in the foreland are thought to directly reflect tectonic and erosional processes in the immediate Alpine hinterland (Matter, 1964; Schlunegger et al., 1993, 1998). The compositional evolution in the basin is diachronous and non-uniform between the different fan systems (e.g. Schlunegger et al., 1998; Spiegel et al., 2000; von 


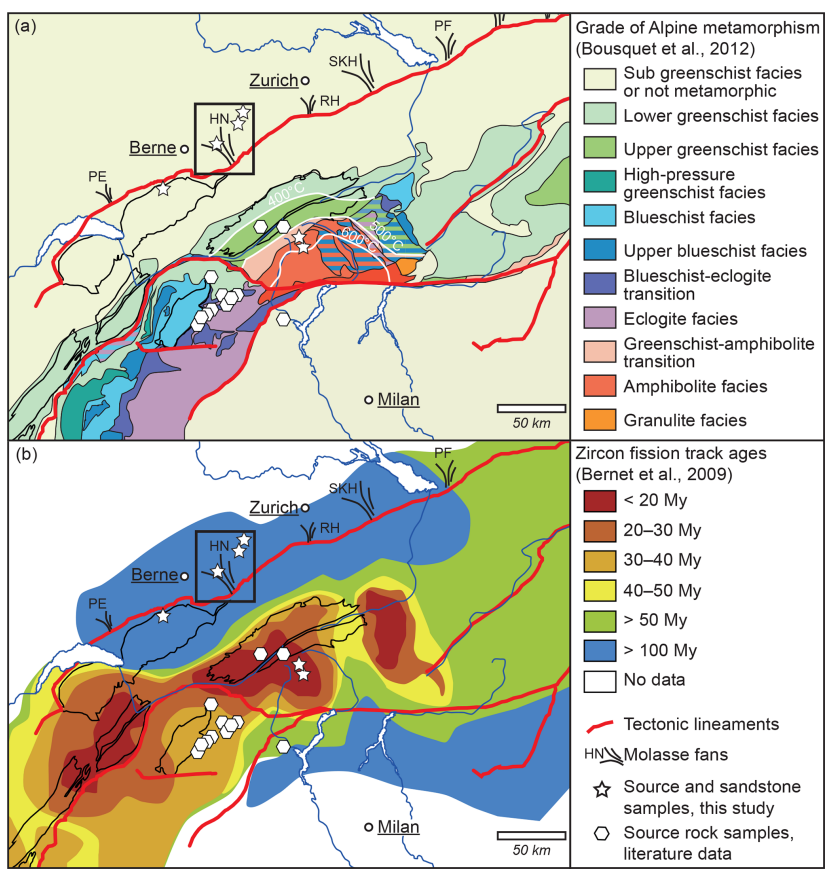

Figure 2. (a) Metamorphic map of the Central Alps (Bousquet et al., 2012) showing the distribution and grade of Alpine metamorphism. Note the increase from north to south from lower greenschist to eclogite facies conditions. (b) In situ bedrock zircon fission track ages according to a compilation of Bernet et al. (2009). Note the predominantly young $(<30 \mathrm{Ma})$ cooling ages in the area around the Lepontine dome and the external massifs in contrast to the predominantly old ( $>50 \mathrm{Ma}$ ) cooling ages in the Austroalpine nappes to the east. The river network (blue) and the thick black outlines of selected geological units (external massifs, Romandes Prealps, and Dent Blanche nappe; cf. Fig. 1) are used to facilitate the orientation and the comparison with Fig. 1. Abbreviations used: PE - Pèlerin fan; HN - Honegg-Napf fan; RH - Rigi-Höhronen fan; SKH - Speer-Kronberg-Hörnli fan; PF - Pfänder fan.

Eynatten, 2003). In this study, we will focus on the HoneggNapf fan, located in the central part of the basin. It most likely preserves a provenance signal related to external massif exhumation due to its proximity to the large crystalline basement slices of the Aar massif and the Gotthard nappe (Fig. 1). In the Honegg-Napf fan, three major compositional trends have been previously identified (Fig. 3).

- Phase 1. Between $\sim 31$ and $\sim 25 \mathrm{Myr}$ ago, the heavy minerals are dominated by the zircon-tourmaline-rutile assemblage and garnet (von Eynatten, 2003). Rock fragments are dominantly of sedimentary origin and zircon fission track ages are Palaeozoic to late Mesozoic (Spiegel et al., 2000). This phase is consistently interpreted to reflect the erosion of Austroalpine flysch-like sedimentary cover nappes, which are structurally the top of the central Alpine nappe stack and probably extended further west during this time (Schlunegger et al., 1998; Spiegel et al., 2000; von Eynatten, 2003).
- Phase 2: 25-21 Myr ago. Around $25 \mathrm{Myr}$ ago, the occurrence of epidote as well as an increase in granitoid rock fragments mark a major compositional change in the foreland. The presence of characteristic colourful granite pebbles suggests an origin from the Austroalpine Bernina nappe (Matter, 1964). Sediments of this phase clearly reflect the cutting down into crystalline basement and are consistent with a continuation of a normal unroofing sequence. Additionally, Schlunegger et al. (1998) report the occurrence of quartzite pebbles, possibly sourced from the middle Penninic Siviez-Mischabel nappe and argue that parts of the epidote could originate from Penninic ophiolites as well, thus suggesting that erosion might have reached down into the Penninic nappes already by then. Spiegel et al. (2002) argued against this Penninic contribution based on the ${ }^{87} \mathrm{Sr} /{ }^{86} \mathrm{Sr}$ and ${ }^{143} \mathrm{Nd} /{ }^{144} \mathrm{Nd}$ isotopic signatures of the epidote.

- Phase 3: 21-14 Myr ago. At $21 \mathrm{Ma}$, metamorphic rock fragments occur in the sediments, whereas the heavy mineral assemblages remain epidote-dominated and overall similar to the second phase. Zircon fission track ages are exclusively Cenozoic (age peaks between $\sim 32$ and $\sim 19 \mathrm{Ma}$ ). In contrast to the first two phases, the sediment composition allows several, partially contradictory interpretations. Whilst petrographic and mineralogic data might suggest recycling and sediment mixing (von Eynatten, 2003), young ${ }^{40} \mathrm{Ar} /{ }^{39} \mathrm{Ar}$ cooling ages in white mica (von Eynatten, 2003; von Eynatten and Wijbrans, 2003) and a population of zircons with a fission track central age of $19.5 \pm 0.9 \mathrm{Ma}$ (Spiegel et al., 2000) point to an additional, newly exhumed source identified as the Lepontine dome (Fig. 2b; von Eynatten, 2003; Spiegel et al., 2000). Based on the abundance of flysch pebbles after $\sim 21 \mathrm{Ma}$, Schlunegger et al. (1998) favour an alternative scenario, in which the erosional front shifted northwards into the flysch nappes of the Romandes Prealps. A mixture of both sources seems possible. Furthermore, the isotopic signature of detrital epidotes suggests a contribution of mantle source rocks between ca. 21 and $19 \mathrm{Myr}$ ago, which could point to a contribution by Penninic ophiolites (Spiegel et al., 2002). However, this is not reflected in the heavy mineral spectra (von Eynatten, 2003) that do not contain typical ophiolite minerals such as $\mathrm{Cr}$ spinel.

The external crystalline massifs have not been regarded as a possible sediment source. The exact time of their surficial exposure is unknown, but it is believed to post-date the youngest preserved Molasse deposits. This interpretation is based on the lack of granitic pebbles attributable to the external massifs in the Molasse (Trümpy, 1980) and on structural reconstructions (e.g. Pfiffner, 1986) in combination with thermochronological data (e.g. Michalski and Soom, 1990). 


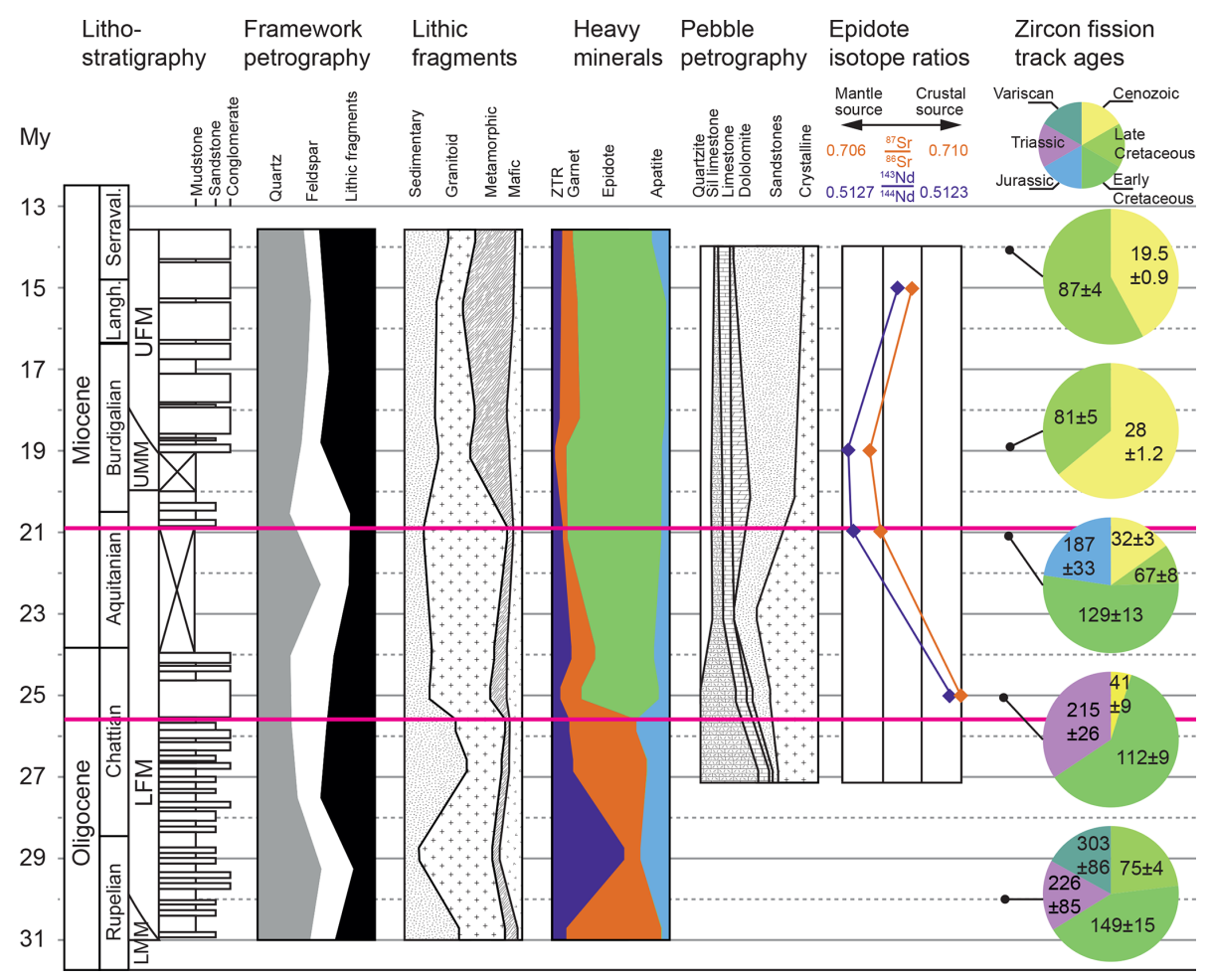

Figure 3. Compilation of published compositional data in the Honegg-Napf fan. Heavy mineral and rock fragment data from the sand grain size after von Eynatten (2003), pebble petrography after Schlunegger et al. (1998), epidote isotope ratios after Spiegel et al. (2002) and zircon fission track (FT) data after Spiegel et al. (2000). The two pink lines represent the dominant provenance changes as discussed in the text. Abbreviations used: LMM - Lower Marine Molasse; LFM - Lower Freshwater Molasse; UMM - Upper Marine Molasse; UFM - Upper Freshwater Molasse; ZTR - zircon-tourmaline-rutile index; sil. - siliceous.

\section{Sampling strategy and methodology}

In order to characterize the detrital garnets in the foreland, three samples were taken from 25, 19, and 14 Myr old fine- to medium-grained fluvial sandstones within the Honegg-Napf fan deposits located ca. $40 \mathrm{~km}$ to the east and southeast of Bern in the central part of the Swiss Molasse basin. The exact sampling sites were chosen based on the availability of published petrographical, chemical, and mineralogical data (von Eynatten, 2003) as well as magnetostratigraphic calibration (Schlunegger et al., 1996).

It is possible to compare potential source compositions to the detrital ones because the potential source rocks were already narrowed down to particular regions based on other provenance proxies and because many of these rocks are still preserved in the Alpine chain today. For comparison we used detrital data from Stutenbecker et al. (2017) as well as published source rock data from different units across the Central Alps (Steck and Burri, 1971; Chinner and Dixon, 1973; Ernst and Dal Piaz, 1978; Hunziker and Zingg, 1980; Oberhänsli, 1980; Sartori, 1990; Thélin et al., 1990; Reinecke, 1998; von Raumer et al., 1999; Cartwright and Barnicoat, 2002; Bucher and Bousquet, 2007; Angiboust et al., 2009; Bucher and Grapes, 2009; Weber and Bucher, 2015).
In addition, three river sand samples were collected from small monolithological catchments $\left(3-30 \mathrm{~km}^{2}\right)$ draining potentially garnet-bearing source rocks that were previously not, or only partially, considered in the literature. We prefer this "tributary sampling approach" (first-order sampling scale according to Ingersoll, 1990) over in situ sampling of specific source rocks because small monolithological catchments are more likely to comprise all garnet varieties of the targeted source rock and to average out spatial variations of the source rock properties, e.g. mineral size or fertility (Malusà et al., 2016). The targeted plausible source areas are located in the Gurnigel flysch (Romandes Prealps), the Antigorio nappe orthogneisses of the Lepontine dome, and the Lebendun nappe paragneisses of the Lepontine dome (Fig. 1). Sample characteristics are summarized in Tables 1 and 2. For detailed lithological descriptions of the sampling sites in the Honegg-Napf area, see Schlunegger et al. (1993) and von Eynatten (2003).

The sandstone samples were carefully disintegrated using a jaw breaker and a pestle and mortar. The disintegrated sandstones and the source rock tributary sands were sieved into four grain size classes of $<63,63-125,125-250$, and $>250 \mu \mathrm{m}$. The fractions of $63-125$ and $125-250 \mu \mathrm{m}$ were further processed in sodium polytungstate heavy liquid at 
Table 1. Sample locations and characteristics of the Molasse sandstones from the Honegg-Napf fan. Abbreviations used: UFM - Upper Freshwater Molasse; UMM - Upper Marine Molasse; LFM - Lower Freshwater Molasse.

\begin{tabular}{|c|c|c|c|c|}
\hline $\begin{array}{l}\text { Sample } \\
\text { name }\end{array}$ & $\begin{array}{l}\text { Sampling } \\
\text { location }\end{array}$ & $\begin{array}{l}\text { Lithostratigraphy } \\
\text { (Matter, 1964; } \\
\text { Schlunegger et al., } \\
\text { 1996) }\end{array}$ & $\begin{array}{l}\text { Magnetostratigraphic } \\
\text { section (Schluneg- } \\
\text { ger et al., 1996) }\end{array}$ & $\begin{array}{l}\text { Magnetostratigraphic } \\
\text { age (Schlunegger et } \\
\text { al., 1996) }\end{array}$ \\
\hline LS2017-3 & $\begin{array}{l}47.00566 \\
7.971325\end{array}$ & UFM, Napf beds & Fontannen section & ca. $14 \mathrm{Ma}$ \\
\hline LS2018-5 & $\begin{array}{l}46.93913 \\
7.950800\end{array}$ & $\begin{array}{l}\text { UMM, Luzern } \\
\text { formation }\end{array}$ & $\begin{array}{l}\text { Schwändigraben } \\
\text { section }\end{array}$ & ca. $19 \mathrm{Ma}$ \\
\hline LS2016-18 & $\begin{array}{l}46.77463 \\
7.732383\end{array}$ & $\begin{array}{l}\text { LFM, Thun } \\
\text { formation }\end{array}$ & $\begin{array}{l}\text { Prässerebach } \\
\text { section }\end{array}$ & ca. $25 \mathrm{Ma}$ \\
\hline
\end{tabular}

Table 2. Sample locations and characteristics of potential sources (tributary sampling approach).

\begin{tabular}{lllll}
\hline $\begin{array}{l}\text { Sample } \\
\text { name }\end{array}$ & $\begin{array}{l}\text { Sampling } \\
\text { location }\end{array}$ & River catchment & Metamorphic grade & Lithological unit \\
\hline LS2018-12 & $\begin{array}{l}46.72026 \\
7.24548\end{array}$ & $\begin{array}{l}\text { Ärgera, } \\
\text { ca. } 30 \mathrm{~km}^{2}\end{array}$ & Not metamorphic & $\begin{array}{l}\text { Gurnigel flysch } \\
\text { (detrital garnets) }\end{array}$ \\
\hline LS2018-40 & $\begin{array}{l}46.39026 \\
8.54124\end{array}$ & $\begin{array}{l}\text { Valle di Foiòi, } \\
\text { ca. } 3 \mathrm{~km}^{2}\end{array}$ & $\begin{array}{l}\text { Alpine amphibolite } \\
\text { facies }\end{array}$ & $\begin{array}{l}\text { Orthogneiss, Antig- } \\
\text { orio nappe, Lepon- } \\
\text { tine dome }\end{array}$ \\
\hline LS2016-43 & $\begin{array}{l}46.43955 \\
8.50115\end{array}$ & $\begin{array}{l}\text { Valletta di Fiorina, } \\
\text { ca. } 8 \mathrm{~km}^{2}\end{array}$ & $\begin{array}{l}\text { Alpine amphibolite } \\
\text { facies }\end{array}$ & $\begin{array}{l}\text { Paragneiss, Leben- } \\
\text { dun nappe, Lepon- } \\
\text { tine dome }\end{array}$ \\
\hline
\end{tabular}

$2.85 \mathrm{~g} \mathrm{~cm}^{-3}$ to concentrate heavy minerals. The heavy mineral concentrates were dried and, depending on the obtained amounts, split into two to four parts using a microsplitter. All analysed garnet grains were hand-picked from the concentrate of one split part per fraction under a binocular microscope.

The grains were subsequently arranged in lines on sticky tape, embedded in epoxy resin, ground with $\mathrm{SiC}$ abrasive paper (grits 400, 800, 1200, 2500, 4000), polished using 3, 1, and $1 / 4 \mu \mathrm{m}$ diamond suspensions, and graphite-coated. Major element oxides were analysed using a JEOL JXA-8200 electron probe micro-analyser at the Institute of Geological Science at University of Bern, Switzerland, under standard operating conditions for garnet (see Giuntoli et al., 2018): accelerating voltage of $15 \mathrm{keV}$; electron beam current of $15 \mathrm{nA}$; beam diameter of $1 \mu \mathrm{m}$; $20 \mathrm{~s}$ peak acquisition time for $\mathrm{Si}$, Ti, $\mathrm{Al}, \mathrm{Fe}, \mathrm{Mn}, \mathrm{Mg}$, and $\mathrm{Ca}$ and $10 \mathrm{~s}$ for both backgrounds. Natural and synthetic standard olivine $\left(\mathrm{SiO}_{2}, \mathrm{MgO}, \mathrm{FeO}\right)$, anorthite $\left(\mathrm{Al}_{2} \mathrm{O}_{3}, \mathrm{CaO}\right)$, ilmenite $\left(\mathrm{TiO}_{2}\right)$, and tephroite $(\mathrm{MnO})$ were used for calibration by applying a CITIZAF correction (Armstrong, 1984). Garnet compositions were measured as close as possible to the geometric centres of the grains, unless the area was heavily fractured or showed inclusions of other minerals. In some randomly selected grains, core and rim compositions were measured to identify intra-grain chemical variability; these core-rim pairs are reported separately in Stutenbecker (2019).

Molecular proportions were calculated from the measured main oxide compositions on the basis of 12 anhydrous oxygen atoms. The $\mathrm{Fe}^{2+} / \mathrm{Fe}^{3+}$ ratio was determined based on charge balance (Locock, 2008) because ferric and ferrous iron were not measured separately (FeO $\left.\mathrm{Fe}_{\text {total }}\right)$. Garnet endmember compositions were subsequently calculated using the Excel spreadsheet by Locock (2008). The relative proportions of the endmember components almandine $\left(\mathrm{Fe}_{3} \mathrm{Al}_{2} \mathrm{Si}_{3} \mathrm{O}_{12}\right)$, grossular $\left(\mathrm{Ca}_{3} \mathrm{Al}_{2} \mathrm{Si}_{3} \mathrm{O}_{12}\right)$, pyrope $\left(\mathrm{Mg}_{3} \mathrm{Al}_{2} \mathrm{Si}_{3} \mathrm{O}_{12}\right)$, spessartine $\left(\mathrm{Mn}_{3} \mathrm{Al}_{2} \mathrm{Si}_{3} \mathrm{O}_{12}\right)$, and andradite $\left(\mathrm{Ca}_{3} \mathrm{Fe}_{2} \mathrm{Si}_{3} \mathrm{O}_{12}\right)$ depend on bulk rock composition and intensive parameters (such as temperature and pressure), which can vary substantially depending on the metamorphic or magmatic history of the protolith (Deer et al., 1992; Spear, 1994). The data were plotted and classified using the ternary diagram of Mange and Morton (2007) as well as the linear discriminant function method of Tolosana-Delgado et al. (2018) based on a global data compilation on garnet compositions from different source rocks (Krippner et al., 2014). 

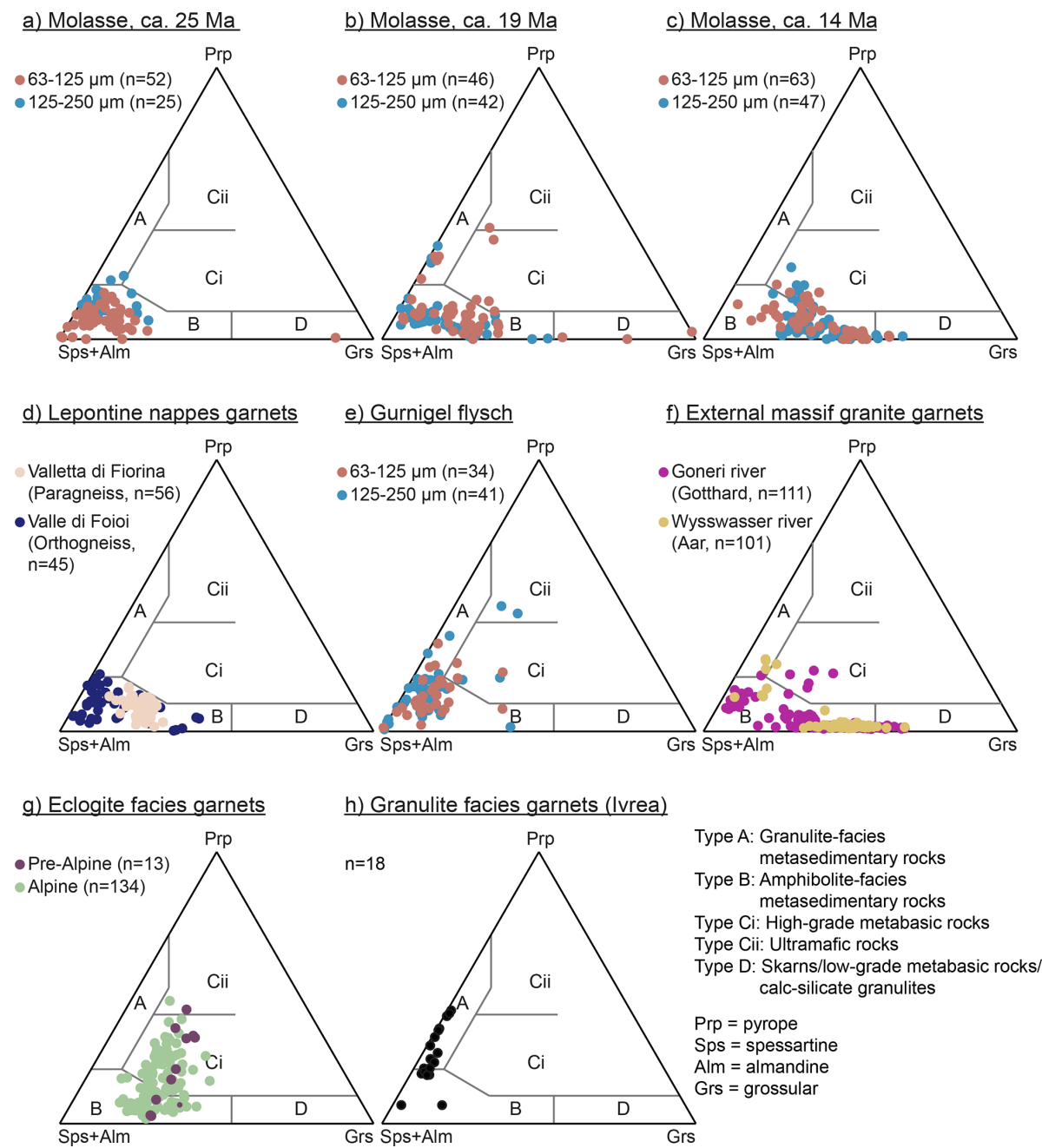

Figure 4. Garnet classification scheme of Mange and Morton (2007). (a-c) Detrital garnet compositions in the 25, 19, and 14 Myr old Molasse deposits (this study). Source rock data from (d) Lepontine gneisses (this study), (e) the Gurnigel flysch (this study), (f) external massif granites (Stutenbecker et al., 2017), (g) eclogite facies rocks (Chinner and Dixon, 1973; Ernst and Dal Piaz, 1978; Oberhänsli, 1980; Sartori, 1990; Thélin et al., 1990; Reinecke, 1998; Cartwright and Barnicoat, 2002; Angiboust et al., 2009; Bucher and Grapes, 2009; Weber and Bucher, 2015), and (h) granulite facies rocks from the Ivrea zone in the southern Alps (Hunziker and Zingg, 1980).

\section{Results}

Most of the detrital garnets are dominated by Fe-rich almandine with varying amounts of grossular, pyrope, spessartine, and andradite (Fig. 4). Other endmembers (e.g. uvarovite) are negligible. Average endmember contents are summarized in Table 3; for the full dataset we refer to Stutenbecker (2019). Garnet compositions do not differ significantly between the two analysed grain size fractions of the same sample, although slight variations are visible (Fig. 4): in sample LS2016-18 (25 Ma; Fig. 4a) garnet of the 125-250 $\mu \mathrm{m}$ fraction is more enriched in pyrope than garnet of the 63-125 $\mu \mathrm{m}$ fraction. In sample LS2018-5 (19 Ma; Fig. 4b) 4 "outliers" that are very pyrope- and grossular-rich $(n=2)$ or grossularand andradite-rich $(n=2)$ occur only in the $63-125 \mu \mathrm{m}$ grain size fraction. Furthermore, garnet grains of the $63-125 \mu \mathrm{m}$ fraction are more frequently grossular-rich compared to the $125-250 \mu \mathrm{m}$ fraction. In sample LS2017-3 (14 Ma; Fig. 4c), the $63-125 \mu \mathrm{m}$ fraction contains some garnet grains $(n=8)$ of high almandine and low grossular content that are absent in the $125-250 \mu \mathrm{m}$ fraction.

Although some individual garnet grains show distinct internal compositional zoning from core to rim, the intragrain chemical variability is generally negligible (see Stutenbecker, 2019).

The major part of garnet in all three samples $(>80 \%)$ belong to the B-type garnet of Mange and Morton (2007) and thus point to a dominant contribution by amphibolite facies source rocks (Table 4). Minor amounts are classified as C-type (high-grade metabasic), A-type (granulite facies), and D-type (metasomatic) garnet. The $25 \mathrm{Myr}$ old sandstone contains almost exclusively B-type garnet (92\%; Table 4). 
Table 3. Average contents (including standard deviation in brackets) of the five common garnet endmembers in the Molasse sandstones, the fluvial samples from the Lepontine gneisses and the Gurnigel flysch (this study), and three potential source rocks from the literature: external crystalline massif granites (Stutenbecker et al., 2017), eclogite facies rocks (Chinner and Dixon, 1973; Ernst and Dal Piaz, 1978; Oberhänsli, 1980; Sartori, 1990; Thélin et al., 1990; Reinecke, 1998; Cartwright and Barnicoat, 2002; Angiboust et al., 2009; Bucher and Grapes, 2009; Weber and Bucher, 2015), and granulite facies rocks (Hunziker and Zingg, 1980). For the full dataset we refer to Stutenbecker (2019).

\begin{tabular}{|c|c|c|c|c|c|}
\hline Sample & Almandine $(\%)$ & Andradite $(\%)$ & Grossular (\%) & Pyrope (\%) & Spessartine $(\%)$ \\
\hline $\begin{array}{l}25 \mathrm{Ma} \\
n=110\end{array}$ & $70(12)$ & $2(5)$ & $9(7)$ & $9(5)$ & $9(8)$ \\
\hline $\begin{array}{l}19 \mathrm{Ma} \\
n=88\end{array}$ & $65(16)$ & $3(13)$ & $16(12)$ & $9(8)$ & $5(6)$ \\
\hline $\begin{array}{l}14 \mathrm{Ma} \\
n=77\end{array}$ & $50(12)$ & $2(2)$ & $32(11)$ & $6(5)$ & $9(9)$ \\
\hline $\begin{array}{l}\text { Valle di Foiòi (Antigo- } \\
\text { rio orthogneiss) } \\
n=45\end{array}$ & $67(10)$ & $1(1)$ & $11(12)$ & $10(6)$ & $10(10)$ \\
\hline $\begin{array}{l}\text { Valletta di Fiorina } \\
\text { (Lebendun paragneiss) } \\
n=56\end{array}$ & $64(5)$ & $0(1)$ & $22(4)$ & $8(3)$ & $5(3)$ \\
\hline $\begin{array}{l}\text { Ärgera river (Gurnigel } \\
\text { flysch) } \\
n=75\end{array}$ & $69(12)$ & $2(1)$ & $9(7)$ & $14(8)$ & $6(9)$ \\
\hline $\begin{array}{l}\text { Goneri and Wysswasser } \\
\text { rivers (external crys- } \\
\text { talline massif granites) } \\
n=212\end{array}$ & $34(16)$ & $0(0)$ & 35 (14) & $4(5)$ & $21(10)$ \\
\hline $\begin{array}{l}\text { Eclogite facies } \\
n=147\end{array}$ & $56(8)$ & $0(1)$ & $23(6)$ & $16(10)$ & $3(5)$ \\
\hline $\begin{array}{l}\text { Granulite facies } \\
n=18\end{array}$ & $67(8)$ & $0(0)$ & $4(1)$ & $25(10)$ & $4(4)$ \\
\hline
\end{tabular}

The $19 \mathrm{Myr}$ old sandstone shows a larger spread with some A-, C-, and D-type garnet (Fig. 4b; Table 4). The $14 \mathrm{Myr}$ old sandstone contains B-, C-, and D-type garnet (Fig. 4c; Table 4). Classification through linear discriminant analysis (Tolosana-Delgado et al., 2018) yields a similar trend with generally high proportions of amphibolite facies source rocks (class-B garnets, $>70 \%$; Table 4). Some grains $(5 \%, 3 \%$, and $12 \%$ in the 25,19 , and 14 Myr old deposits, respectively) were classified as igneous garnet (Table 4).

Distinct compositional changes between the 25, 19, and 14 Myr old Molasse sandstones are mostly related to the ratio of almandine and grossular contents (Table 3, Fig. 5). At $25 \mathrm{Ma}$, the garnets are dominantly almandine-rich (average $70 \%$ ) and grossular-poor (average $9 \%$ ). At $19 \mathrm{Ma}$, both grossular-poor and grossular-richer garnets occur (average $16 \%$ ). Garnets in the $14 \mathrm{Myr}$ old sandstone are generally almandine-poorer (average $50 \%$ ) and grossular-rich (average $32 \%)$.

Garnets from the Lepontine gneisses (Table 3, Fig. 4d) are generally almandine-rich, but those in the paragneiss tend to be grossular-richer (22\%) compared to the ones in the orthogneiss (11\%). The Gurnigel flysch garnets (Fig. 4e) are almandine-rich with elevated pyrope contents (14\%).

\section{Discussion}

\subsection{Late Oligocene ( 25 Myr ago)}

Although detrital garnet chemistry suggests the presence of only one relatively uniform, amphibolite facies source rock in the hinterland of the Honegg-Napf fan during the late Oligocene, the identification of the exact nature of this source is difficult. This is mostly due to the large compositional overlap of garnet sourced by diverse amphibolite facies metamorphic rocks (e.g. metasedimentary versus meta-igneous; Krippner et al., 2014; Tolosana-Delgado et al., 2018).

Amphibolite facies conditions of Alpine age were only reached in the Lepontine dome (Fig. 2a; Bousquet et al., 2012). However, many gneisses in the Central Alps preserve a prealpine amphibolite facies metamorphic signature as well 
Table 4. Results from classification following Mange and Morton (2007) and Tolosana-Delgado et al. (2018). Using the linear discriminant method of Tolosana-Delgado et al. (2018), garnet was attributed to one single class if the probability for that class was $\geq 50 \%$. Several grains were assigned mixed probabilities with $<50 \%$ per class; these are listed separately below (italic numbers).

\begin{tabular}{|c|c|c|c|c|c|c|c|}
\hline & \multicolumn{4}{|c|}{ Mange and Morton (2007) } & \multicolumn{3}{|c|}{ Tolosana-Delgado et al. (2018) } \\
\hline $\begin{array}{l}\text { Types after Mange and } \\
\text { Morton (2007) }\end{array}$ & $25 \mathrm{Ma}$ & $19 \mathrm{Ma}$ & $14 \mathrm{Ma}$ & $\begin{array}{l}\text { Classes after Tolosana- } \\
\text { Delgado et al. (2018) }\end{array}$ & $25 \mathrm{Ma}$ & $19 \mathrm{Ma}$ & $14 \mathrm{Ma}$ \\
\hline $\begin{array}{l}\text { Ci type (high-grade } \\
\text { metabasic) }\end{array}$ & & $5 \%$ & $15 \%$ & Eclogites (Class A) & & $1 \%$ & \\
\hline $\begin{array}{l}\text { B type } \\
\text { (amphibolite facies) }\end{array}$ & $96 \%$ & $84 \%$ & $80 \%$ & Amphibolites (Class B) & $92 \%$ & $81 \%$ & $78 \%$ \\
\hline $\begin{array}{l}\text { A type (granulite } \\
\text { facies) }\end{array}$ & $3 \%$ & $8 \%$ & & Granulites (Class C) & & $9 \%$ & $5.5 \%$ \\
\hline \multirow[t]{3}{*}{ D type (metasomatic) } & $1 \%$ & $3 \%$ & $5 \%$ & Igneous (Class E) & $7 \%$ & $3 \%$ & $12 \%$ \\
\hline & & & & $\begin{array}{l}\text { Mixed probabilities } \\
\text { Classes B-C }\end{array}$ & $1 \%$ & $1 \%$ & \\
\hline & & & & $\begin{array}{l}\text { Mixed probabilities } \\
\text { Classes } A-B-C\end{array}$ & & $5 \%$ & $4.5 \%$ \\
\hline
\end{tabular}
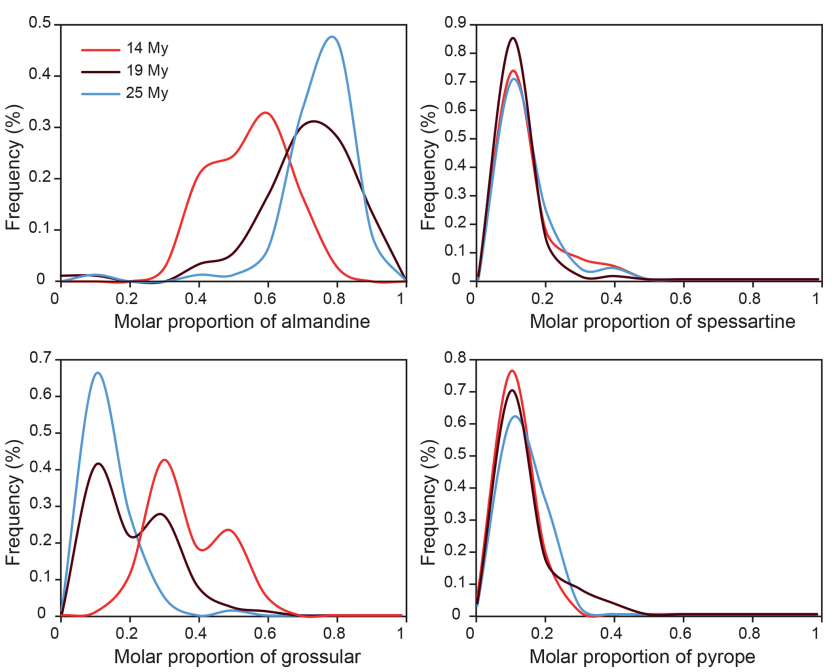

Figure 5. Relative frequency of the four most common endmembers almandine, grossular, spessartine, and pyrope in the three detrital samples from the Molasse basin.

(Frey et al., 1999), for example in the Austroalpine Bernina nappe (Spillmann, 1993; Spillmann and Büchi, 1993), the middle Penninic Briançonnais basement (Sartori et al., 2006), or the polycyclic basement of the external massifs (von Raumer et al., 1999). In fact, the Gurnigel flysch, a Late Cretaceous to Eocene flysch nappe in the Romandes Prealps that did not undergo Alpine metamorphism (Fig. 2a), contains abundant almandine-rich B-type garnets (Fig. 4e).
Zircon fission track ages from sandstones of the same age are mostly $>100 \mathrm{Myr}$ old with a smaller and younger age peak of $41 \pm 9 \mathrm{Ma}$ (Fig. 3; Spiegel et al., 2000). This would favour an input from the Austroalpine nappes and/or the Romandes Prealps (Fig. 6a), which yield related cooling ages $>50 \mathrm{Ma}$ (Fig. 2b; e.g. Bernet et al., 2009), rather than from the Lepontine dome, which is characterized by zircon fission track ages $<30 \mathrm{Ma}$ (Fig. 2b; e.g. Hurford, 1986). The presence of granite pebbles attributable to the Austroalpine Bernina nappe (Matter, 1964; Schlunegger et al., 1998) would further support an Austroalpine rather than a Lepontine provenance.

The drainage divide was probably located close to the Insubric line (e.g. Schlunegger et al., 1998) but north of the Bergell pluton (Fig. 6a), whose detritus is exclusively found in the retro-foreland to the south (Gonfolite Lombarda; Giger and Hurford, 1989; Carrapa and Di Giulio, 2001).

\subsection{Early Miocene ( 19 Myr ago)}

The larger spread of garnet compositions in the early Miocene $(\sim 19 \mathrm{Ma})$ sample indicates the presence of several or mixed sources with different metamorphic grades, including amphibolite-, eclogite-, and granulite facies rocks.

The B-type garnet compositions match the range of garnets found in the Lepontine nappes (Fig. 4b, d), which is supported by the occurrence of predominantly young $(<30 \mathrm{Ma})$ zircon fission track ages (Fig. 3) in agreement with the young cooling ages of the Lepontine dome (Fig. 2b; Bernet et al., 2009). Due to the overlap of amphibolite facies garnets, it cannot be excluded that at least some of the garnets were contributed by Austroalpine sources or were recycled from 

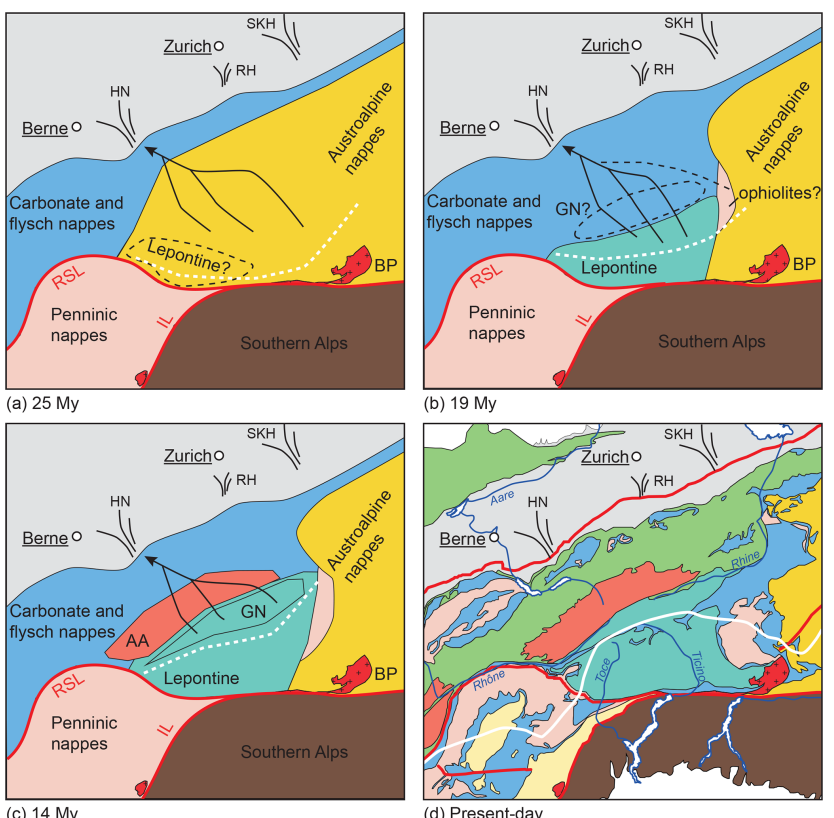

(b) $19 \mathrm{My}$

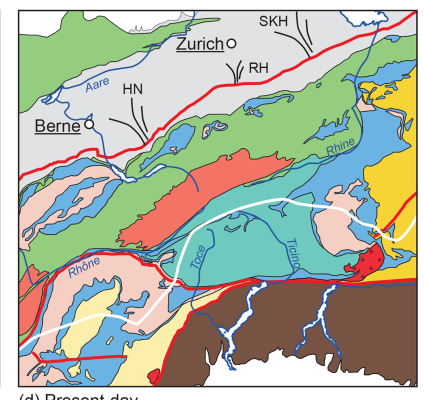

(d) Present-day

Figure 6. Paleogeographic reconstruction of the Central Alps and in particular of the hinterland of the Honegg-Napf fan. Situation during (a) the late Oligocene $(\sim 25 \mathrm{Ma})$, (b) the early Miocene ( $\sim 19 \mathrm{Ma}),(\mathbf{c})$ the middle Miocene $(\sim 14 \mathrm{Ma})$, and (d) today (after Schmid et al., 2004). The colour coding in (a-c) corresponds essentially to the colour coding in (d) (see Fig. 1 for detailed legend). However, we have summarized the lower, middle, and upper Penninic nappes and the Dent Blanche nappe (pink colour) as well as the carbonate and flysch nappes of the Helvetic nappes and the Romandes Prealps (blue colour). Abbreviations used: AA - Aar massif; BP - Bergell pluton; GN - Gotthard nappe; HN - Honegg-Napf fan; IL - Insubric line; RH - Rigi-Höhronen fan; RSL - RhôneSimplon lineament; SKH - Speer-Kronberg-Hörnli fan.

older strata. The Lepontine dome was probably drained both towards the north and the south (Fig. 6b) because old basement detritus with young cooling ages $(\sim 30 \mathrm{Ma}$; derived from K-Ar on white mica) was found in the Gonfolite Lombarda group in the southern retro-foreland (Giger and Hurford, 1989).

Granulite facies metamorphic conditions in the Central Alps were only reached in the Gruf complex located close to the Insubric line between the Lepontine dome and the Bergell intrusion (Fig. 2a). Furthermore, there is evidence for pre-Mesozoic granulite facies metamorphism in some rocks in the southern Alpine Ivrea zone south of the Insubric line (Hunziker and Zingg, 1980), in the Sesia Zone (Fig. 1; Engi et al., 2018; Giuntoli et al., 2018), and in the Dent Blanche nappe (Fig. 1; Angiboust et al., 2009). It is unlikely that erosion reached that far to the south during the Miocene because the Penninic and probably also the exhuming Lepontine nappe stack would have acted as a topographic barrier to the fluvial drainage network (Fig. 6b). However, it has been proposed that the flysch deposits preserved in the Romandes

Prealps were partially fed by these units during the Late Cretaceous and the Eocene (Wildi, 1985; Ragusa et al., 2017). This interpretation is supported by the Gurnigel flysch sample (Fig. 4e), which contains garnets of the granulite facies type that are similar to those found in the Ivrea zone (Table 3, Fig. 4h). A recycled flysch origin is supported further by the abundance of flysch sandstone pebbles in Molasse strata of the same age (Schlunegger et al., 1998).

A potential, but minor, contribution from ophiolites, as suggested by Spiegel et al. (2002), could be supported by the two eclogite facies garnet grains found in the $19 \mathrm{Myr}$ old sample (Fig. 4b) that match eclogite facies garnets from Alpine ophiolites (Table 3, Fig. 4g). Eclogite facies garnets occur both in metamorphic rocks of the Penninic Alpine ophiolites (e.g. Bucher and Grapes, 2009; Weber and Bucher, 2015; Fig. 2a) and in Palaeozoic (?) gneisses of the middle Penninic Briançonnais basement (Sartori, 1990; Thélin et al., 1990). Both sources are not distinguishable (Fig. 4g) but would have probably been located in relative close geographic proximity, either in the Penninic hanging wall south of the Simplon fault (Zermatt area) or in the Penninic nappes located between the eastern rim of the Lepontine and the adjacent Austroalpine nappes (Arosa zone; Fig. 6b).

\subsection{Middle Miocene ( 14 Myr ago)}

Previous provenance studies have identified metasedimentary detritus in the middle Miocene Molasse and located its source in the unroofing sedimentary cover of the Lepontine dome (e.g. von Eynatten, 2003). This was strongly supported by the young detrital zircon fission track ages (youngest peak at $19.5 \pm 0.9 \mathrm{Ma}$, Fig. 3; Spiegel et al., 2000) that match the zircon fission track ages of the Lepontine dome (Fig. 2b; e.g. Hurford, 1986; Bernet et al., 2009).

However, garnet compositions in the youngest Molasse sandstones are not comparable to Lepontine garnets sampled in this study nor to any detrital garnet found in the main rivers draining the Lepontine dome today (Andò et al., 2014). Instead, the detrital garnet signature of the $14 \mathrm{Myr}$ old sample mirrors almost exactly the compositional range of garnets from the external crystalline massifs (Table 3, Fig. 4c, f). In the external crystalline massifs, these garnets grew in PermoCarboniferous plutons under Alpine greenschist facies metamorphic conditions (Steck and Burri, 1971, Fig. 2a). They are restricted to the granitoid basement of the external massifs and do not occur anywhere else in the Central Alps, which makes them an excellent provenance proxy (Stutenbecker et al., 2017). A further distinction among garnets supplied by the different plutons (e.g. the Central Aar granite from the Aar massif, the Rotondo granite from the Gotthard nappe and the Mont Blanc granite from the Mont Blanc massif) is not possible based on major element garnet geochemistry alone (Stutenbecker et al., 2017). Until now, the surficial exposure of the external massifs in the Central Alps was thought to post-date Molasse deposition. This interpretation 


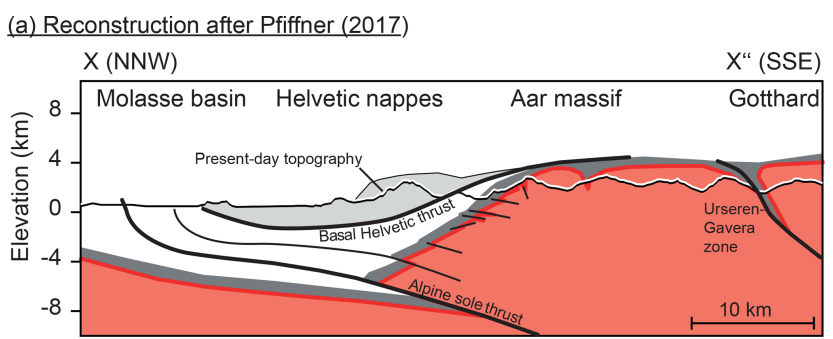

(b) Reconstruction after Nibourel et al. (2018)

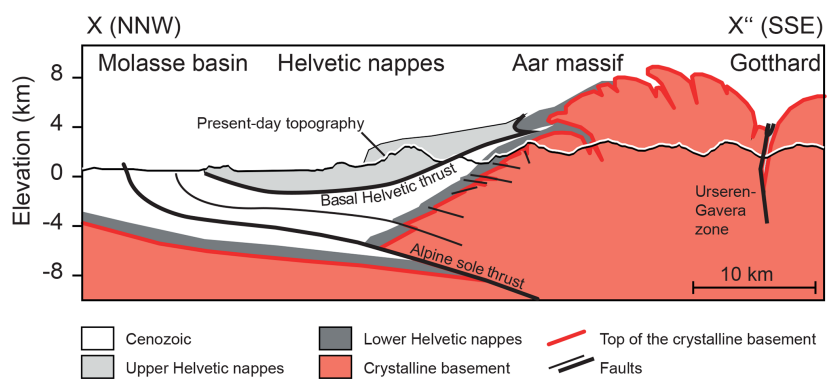

Figure 7. Cross sections from $X$ to $X^{\prime \prime}$ in Fig. 1 through the Aar massif simplified after Pfiffner (2017) and Nibourel et al. (2018). (a) The reconstructed top of the crystalline basement in the Aar massif is located ca. 1-2 km higher than the present-day topography according to Pfiffner (2017). (b) In a revised version by Nibourel et al. (2018) the contact between the basement and the overlying Helvetic cover nappes is reconstructed to be steeper, resulting in ca. $8 \mathrm{~km}$ of (now eroded) crystalline crust on top of the present-day topography.

relies principally on the absence of pebbles of external massif origin (e.g. Aare granite) in the foreland basin (Trümpy, 1980). However, many Alpine granite bodies closely resemble each other mineralogically and texturally, especially if present as altered pebbles in the Molasse deposits, and hence it is difficult to discount a specific source only on this basis. Further support of late surficial exposure of the external massifs comes from structural reconstructions (e.g. Pfiffner, 1986, 2017) that have located the top of the crystalline basement at an elevation that is similar to the modern topography, based on a relatively flat-lying contact between the crystalline basement and the overlying Mesozoic sedimentary cover (Fig. 7a). According to this model and the published exhumation rates of $0.5-0.7 \mathrm{~km} \mathrm{Myr}^{-1}$ (Michalski and Soom, 1990; Glotzbach et al., 2010), the top of the basement was buried 7-10 km below the surface $14 \mathrm{Myr}$ ago.

However, Nibourel et al. (2018) recently proposed a revised geometry of the contact between crystalline basement and overlying cover, which allows ca. $8 \mathrm{~km}$ of additional crystalline basement on top of the present-day topography (Fig. 7b). The presence of external massif-sourced garnets in the youngest Molasse deposits provides independent evidence that parts of the crystalline crust contained in the external massifs were already at the surface at ca. $14 \mathrm{Ma}$ (Fig. 6c). Assuming the aforementioned average exhuma- tion rates, $7-10 \mathrm{~km}$ of crystalline basement would have already been exhumed and subsequently eroded during the past $14 \mathrm{Myr}$, which is in good agreement with the geometric reconstructions by Nibourel et al. (2018).

We suggest that the drainage divide was shifted northwards due to the exhumation of the Gotthard nappe and/or the Aar massif and that it was essentially located at its current position (Fig. 6c, d), but this warrants corroboration from other deposits in the foreland and the retro-foreland.

\section{Conclusions}

Garnet geochemistry is a useful tool to further constrain the provenance of sandstones in orogens such as the Central Alps. We have demonstrated that it is possible to distinguish detrital garnets using a combination of garnet classification schemes (Mange and Morton, 2007; Tolosana-Delgado et al., 2018) and case-specific comparison with available Alpine source rock compositions (Stutenbecker et al., 2017). For the Miocene deposits of the Swiss Molasse basin, we were able to (1) confirm the provenance shift possibly related to the exhumation of the Lepontine dome between 25 and $19 \mathrm{Myr}$ ago as suggested previously (e.g. von Eynatten, 2003) and (2) to identify an additional provenance shift between ca. 19 and $14 \mathrm{Myr}$ ago that had not been noticed before. This shift is related to the erosion of granites from the external crystalline massifs, which provides a minimum age for their surficial exposure and corroborates their recently revised structural geometry. We conclude that the exposure of the crystalline basement happened already ca. $14 \mathrm{Myr}$ ago, which is several million years earlier than previously assumed.

Data availability. The data (chemical composition of garnets from Molasse sandstones and source samples) can be found online: https://doi.org/10.6084/m9.figshare.8269742.v1 (Stutenbecker, 2019).

Author contributions. LS designed the project. AM helped during field work and sample collection. PMET and PL gave advice for sample preparation and supported the microprobe measurements and data acquisition at the University of Bern. LS prepared the paper with contributions by all co-authors.

Competing interests. The authors declare that they have no conflict of interest.

Acknowledgements. We would like to thank Fritz Schlunegger for guidance in the field and Alfons Berger and Lukas Nibourel for stimulating discussions. We thank reviewers Carita Augustsson and Lorenzo Gemignani for their constructive comments. 
Financial support. This research has been supported by the International Association of Sedimentologists (post-doctoral research grant, spring session 2018 grant).

Review statement. This paper was edited by Kei Ogata and reviewed by Carita Augustsson and Lorenzo Gemignani.

\section{References}

Allen, P. A., Crampton, S. L., and Sinclair, H. D.: The inception and early evolution of the North Alpine Foreland Basin, Switzerland, Basin Res., 3, 143-163, 1991.

Andò, S., Morton, A. C., and Garzanti, E.: Metamorphic grade of source rocks revealed by chemical fingerprints of detrital amphibole and garnet, Geol. Soc. Spec. Publ., 386, 351-371, https://doi.org/10.1144/SP386.5, 2014.

Angiboust, S., Agard, P., Jolivet, L., and Beyssac, O.: The Zermatt-Saas ophiolite: The largest $(60-\mathrm{km}$ wide) and deepest (c. 70-80 km) continuous slice of oceanic lithosphere detached from a subduction zone?, Terra Nova, 21, 171-180, https://doi.org/10.1111/j.1365-3121.2009.00870.x, 2009.

Armstrong, J. T.: Quantitative analysis of silicate and oxide minerals: a reevaluation of ZAF corrections and proposal for new Bence-Albee coefficients, in: Microbeam Analysis, edited by: Romig, A. D. and Goldstein, J. I., San Francisco Press, USA, 208-212, 1984.

Baran, R., Friedrich, A. M., and Schlunegger, F.: The late Miocene to Holocene erosion pattern of the Alpine foreland basin reflects Eurasian slab unloading beneath the western Alps rather than global climate change, Lithosphere, 6, 124-131, https://doi.org/10.1130/L307.1, 2014.

Berger, A., Mercolli, I., and Engi, M.: The central Lepontine Alps: Notes accompanying the tectonic and petrographic map sheet Sopra Ceneri (1:100’000), Schweiz. Miner. Petrog., 85, 109-146, 2005.

Bernet, M., Brandon, M., Garver, J., Balestieri, M. L., Ventura, B., and Zattin, M.: Exhuming the Alps through time: clues from detrital zircon fission-track thermochronology, Basin Res., 21, 781-798, https://doi.org/10.1111/j.1365-2117.2009.00400.x, 2009.

Bousquet, R., Oberhänsli, R., Schmid, S. M., Berger, A., Wiederkehr, M., Robert, C., Möller, A., Rosenberg, C., Zeilinger, G., Molli, G., and Koller, F.: Metamorphic Framework of the Alps, Commission for the geological map of the world, Paris, 2012.

Bucher, S. and Bousquet, R.: Metamorphic evolution of the Brianconnais units along the ECORS-CROP profile (Western Alps): New data on metasedimentary rocks, Swiss J. Geosci., 100, 227242, https://doi.org/10.1007/s00015-007-1222-4, 2007.

Bucher, K. and Grapes, R: The eclogite-facies Allalin gabbro of the Zermatt-Saas ophiolite, Western alps: A record of subduction zone hydration, J. Petrol., 50, 1405-1442, https://doi.org/10.1093/petrology/egp035, 2009.

Carrapa, B. and Di Giulio, A.: The sedimentary record of the exhumation of a granitic intrusion into a collisional setting: The lower Gonfolite Group, Southern Alps, Italy, Sedimentary Geol., 139, 217-228, 2001.
Cartwright, I. and Barnicoat, A. C.: Petrology, geochronology, and tectonics of shear zones in the Zermatt-Saas and Combin zones of the Western Alps, J. Metamorph. Geol., 20, 263-281, 2002.

Cederbom, C. E., Sinclair, H. D., Schlunegger, F., and Rahn, M. K.: Climate-induced rebound and exhumation of the European Alps, Geology, 32, 709-712, https://doi.org/10.1130/G20491.1, 2004.

Cenki-Tok, B., Darling, J. R., Rolland, Y., Dhuime, B., and Storey, C. D.: Direct dating of mid-crustal shear zones with synkinematic allanite: New in situ U-Th- $\mathrm{Pb}$ geochronological approaches applied to the Mont Blanc massif, Terra Nova, 26, 2937, https://doi.org/10.1111/ter.12066, 2014.

Challandes, N., Marquer, D., and Villa, I. M.: P-T-t modelling, fluid circulation, and39Ar-40Ar and Rb-Sr mica ages in the Aar Massif shear zones (Swiss Alps), Swiss J. Geosci., 101, 269-288, https://doi.org/10.1007/s00015-008-1260-6, 2008.

Champagnac, J.-D., Schlunegger, F., Norton, K., von Blanckenburg, F., Abbühl, L. M., and Schwab, M.: Erosion-driven uplift of the modern Central Alps, Tectonophysics, 474, 236-249, https://doi.org/10.1016/j.tecto.2009.02.024, 2009.

Chinner, G. A. and Dixon, J. E.: Some high-pressure parageneses of the allalin gabbro, Valais, Switzerland, J. Petrol., 14, 185-202, https://doi.org/10.1093/petrology/14.2.185, 1973.

Deer, W., Howie, R. A., and Zussmann, J.: An introduction to the rock-forming minerals, New Jersey: Prentice Hall, 1992.

Engesser, B.: Die Eomyidae (Rodentia, Mammalia) der Molasse der Schweiz und Savoyens. Systematik und Biostratigraphie, Schweizer Paläontologische Abhandlungen (112), Basel: Birkhäuser Verlag, 1990.

Engi, M., Giuntoli, F., Lanari, P., Burn, M., Kunz, B., and Bouvier, A. S.: Pervasive Eclogitization Due to Brittle Deformation and Rehydration of Subducted Basement: Effects on Continental Recycling?, Geochem. Geophy. Geosy., 19, 865-881, https://doi.org/10.1002/2017GC007215, 2018.

Ernst, W. G. and Dal Piaz, G. V.: Mineral parageneses of eclogitic rocks and related mafic schists of the Piemonte ophiolite nappe, Breuil-St Jacques area, Italian Western Alps, Amer. Mineral., 63, 621-640, 1978.

Fox, M., Herman, F., Kissling, E., and Willett, S. D.: Rapid exhumation in the Western Alps driven by slab detachment and glacial erosion, Geology, 43, 379-382, https://doi.org/10.1130/G36411.1, 2015.

Frey, M. and Ferreiro Mählmann, R.: Alpine metamorphism of the Central Alps. Schweiz. Miner. Petrog., 79, 135-154, 1999.

Frey, M., Desmons, J., and Neubauer, F.: The new metamorphic map of the Alps?: introduction, Schweiz. Miner. Petrog., 79, 1-4, https://doi.org/10.5169/seals-60194, 1999.

Froitzheim, N., Schmid, S. M., and Frey, M.: Mesozoic paleogeography and the timing of eclogitefacies in the Alps: A working hypothesis, Eclogae Geol. Helv., 110, 81-110, 1996.

Garzanti, E. and Andò, S.: Plate Tectonics and Heavy Mineral Suites of Modern Sands, in: Heavy minerals in use, edited by: Mange, M. A. and Wright, D. T., Developments in Sedimentology Series, 58, 741-763, https://doi.org/10.1016/S00704571(07)58029-5, 2007.

Gebauer, D.: Alpine geochronology of the Central and Western Alps: new constraints for a complex geodynamic evolution, Schweiz. Miner. Petrog., 79, 191-208, https://doi.org/10.5169/seals-60205, 1999. 
Giger, M. and Hurford, A. J.: Tertiary intrusives of the Central Alps: Their Tertiary uplift, erosion, redeposition and burial in the south-alpine foreland, Eclogae Geol. Helv., 82, 857-866, 1989.

Giuntoli, F., Lanari, P., and Engi, M.: Deeply subducted continental fragments - Part 1: Fracturing, dissolution-precipitation, and diffusion processes recorded by garnet textures of the central Sesia Zone (western Italian Alps), Solid Earth, 9, 167-189, https://doi.org/10.5194/se-9-167-2018, 2018.

Glotzbach, C., Reinecker, J., Danišík, M., Rahn, M., Frisch, W., and Spiegel, C.: Thermal history of the central Gotthard and Aar massifs, European Alps: Evidence for steady state, long-term exhumation, J. Geophys. Res.-Earth, 115, F03017, https://doi.org/10.1029/2009JF001304, 2010.

Handy, M. R., M. Schmid, S., Bousquet, R., Kissling, E., and Bernoulli, D.: Reconciling plate-tectonic reconstructions of Alpine Tethys with the geological-geophysical record of spreading and subduction in the Alps, Earth-Sci. Rev., 102, 121-158, https://doi.org/10.1016/j.earscirev.2010.06.002, 2010.

Herman, F., Seward, D., Valla, P. G., Carter, A., Kohn, B., Willett, S. D., and Ehlers, T. A.: Worldwide acceleration of mountain erosion under a cooling climate, Nature, 504, 423-426, https://doi.org/10.1038/nature12877, 2013.

Herwegh, M., Berger, A., Baumberger, R., Wehrens, P., and Kissling, E.: Large-Scale Crustal-Block-Extrusion During Late Alpine Collision, Sci. Rep.-UK, 7, 413, https://doi.org/10.1038/s41598-017-00440-0, 2017.

Hunziker, J. C. and Zingg, A.: Lower palaeozoic amphibolite to granulite facies metamorphism in the Ivrea zone (Southern Alps, Northern Italy), Schweiz. Miner. Petrog., 60, 181-213, 1980.

Hurford, A. J.: Cooling and uplift patterns in the Lepontine Alps South Central Switzerland and an age of vertical movement on the Insubric fault line, Contrib. Mineral. Petr., 92, 413-427, https://doi.org/10.1007/BF00374424, 1986.

Ingersoll, R. V.: Actualistic sandstone petrofacies: Discriminating modern and ancient source rocks, Geology, 18, 733-736, 1990.

Janots, E., Engi, M., Rubatto, D., Berger, A., Gregory, C., and Rahn, M.: Metamorphic rates in collisional orogeny from in situ allanite and monazite dating, Geology, 37, 11-14, https://doi.org/10.1130/G25192A.1, 2009.

Kempf, O., Matter, A., Burbank, D. W., and Mange, M.: Depositional and structural evolution of a foreland basin margin in a magnetostratigraphic framework: The eastern Swiss Molasse Basin, Int. J. Earth Sci., 88, 253-275, https://doi.org/10.1007/s005310050263, 1999.

Krippner, A., Meinhold, G., Morton, A. C., and von Eynatten, H.: Evaluation of garnet discrimination diagrams using geochemical data of garnets derived from various host rocks, Sedimentary Geol., 306, 36-52, https://doi.org/10.1016/j.sedgeo.2014.03.004, 2014.

Kuhlemann, J. and Kempf, O.: Post-Eocene evolution of the North Alpine Foreland Basin and its response to Alpine tectonics, Sedimentary Geol., 152, 45-78, https://doi.org/10.1016/S00370738(01)00285-8, 2002

Kuhlemann, J., Frisch, W., Székely, B., Dunkl, I., and Kázmér, M.: Post-collisional sediment budget history of the Alps: tectonic versus climatic control, Int. J. Earth Sci., 91, 818-837, https://doi.org/10.1007/s00531-002-0266-y, 2002.

Kühni, A. and Pfiffner, O. A.: The relief of the Swiss Alps and adjacent areas and its relation to lithology and structure: Topo- graphic analysis from a 250-m DEM, Geomorphology, 41, 285307, https://doi.org/10.1016/S0169-555X(01)00060-5, 2001.

Locock, A. J.: An Excel spreadsheet to recast analyses of garnet into end-member components, and a synopsis of the crystal chemistry of natural silicate garnets, Comput. Geosci., 34, 1769-1780, https://doi.org/10.1016/j.cageo.2007.12.013, 2008.

Malusà, M., Resentini, A., and Garzanti, E.: Hydraulic sorting and mineral fertility bias in detrital geochronology, Gondwana Res., 31, 1-19, https://doi.org/10.1016/j.gr.2015.09.002, 2016.

Mange, M. A. and Morton, A. C.: Geochemistry of heavy minerals, in: Heavy minerals in use, edited by: Mange, M. A. and Wright, D. T., Developments in Sedimentology series, 58, 345391, 2007.

Matter, A.: Sedimentologische Untersuchungen im östlichen Napfgebiet (Entlebuch - Tal der Grossen Fontanne, Kt. Luzern), Eclogae Geol. Helv., 57, 315-428, 1964.

Michalski, I. and Soom, M.: The Alpine thermo-tectonic evolution of the Aar and Gotthard massifs, Central Switzerland - Fission Track ages on zircon and apatite and K-Ar mica ages, Schweiz. Miner. Petrog., 70, 373-387, https://doi.org/10.5169/seals53628, 1990.

Morton, A. C. and Hallsworth, C.: Stability of Detrital Heavy Minerals During Burial Diagenesis, in: Heavy minerals in use, edited by: Mange, M. A. and Wright, D. T., Developments in Sedimentology series, 58, 215-245, https://doi.org/10.1016/S00704571(07)58007-6, 2007.

Nibourel, L., Berger, A., Egli, D., Luensdorf, N. K., and Herwegh, M.: Large vertical displacements of a crystalline massif recorded by Raman thermometry, Geology, 46, 879-882, https://doi.org/10.1130/G45121.1, 2018.

Oberhänsli, R.: P-T Bestimmungen anhand von Mineralanalysen in Eklogiten und Glaukophaniten der Ophiolite von Zermatt, Schweiz. Miner. Petrog., 60, 215-235, https://doi.org/10.5169/seals-46668, 1980.

Oberhänsli, R., Bousquet, R., Engi, M., Goffé, B., Gosso, G., Handy, M. R., Höck, V., Koller, F.. Lardeaux, J. M., Polino, R., Rossi, P. L., Schuster, R., Schwartz, S., and Spalla, I.: Metamorphic Structure of the Alps, Commission for the geological map of the world, Paris, 2004.

Pfiffner, O. A.: Evolution of the north Alpine foreland basin in the Central Alps, in: Foreland basins, edited by: Allen, P. A. and Homewood, P., Int. As. Sed., 8, 219-228, 1986.

Pfiffner, O. A.: Thick-Skinned and Thin-Skinned Tectonics: A Global Perspective, Geosciences, 7, 71, https://doi.org/10.3390/geosciences7030071, 2017.

Pfiffner, O. A., Schlunegger, F., and Buiter, S. J. H.: The Swiss Alps and their peripheral foreland basin: Stratigraphic response to deep crustal processes, Tectonics, 21, 3.1-3.16, https://doi.org/10.1029/2000TC900039, 2002.

Ragusa, J., Kindler, P., Šegvić, B., and Ospina-Ostios, L. M.: Provenance analysis of the Voirons Flysch (Gurnigel nappe, Haute-Savoie, France): stratigraphic and palaeogeographic implications, Springer Berlin Heidelberg, 106, 26192651, https://doi.org/10.1007/s00531-017-1474-9, 2017.

Reinecke, T.: Prograde high- to ultrahigh-pressure metamorphism and exhumation of oceanic sediments at Lago di Cignana, Zermatt-Saas Zone, western Alps, Lithos, 42, 147-189, https://doi.org/10.1016/S0024-4937(97)00041-8, 1998. 
Rolland, Y., Rossi, M., Cox, S. F., Corsini, M., Mancktelow, N., Pennacchioni, G., Fornari, M., and Boullier, A. M.: 40Ar/39Ar dating of synkinematic white mica: insights from fluid-rock reaction in low-grade shear zones (Mont Blanc Massif) and constraints on timing of deformation in the NW external Alps, Geol. Soc. Spec. Publ., 299, 293-315, https://doi.org/10.1144/SP299.18, 2008.

Sartori, M.: L'unite du Barrhorn (Zone pennique, Valais, Suisse), Mémoires de Géologie 6, Lausanne, Switzerland, 1990.

Sartori, M., Gouffon, Y., and Marthaler, M.: Harmonisation et définition des unités lithostratigraphiques briançonnaises dans les nappes penniques du Valais, Eclogae Geol. Helv., 99, 363-407, https://doi.org/10.1007/s00015-006-1200-2, 2006.

Schaer, J. P., Reimer, G. M., and Wagner, G. A.: Actual and ancient uplift rate in the Gotthard region, Swiss Alps: A comparison between precise levelling and Fission-Track Apatite age, Tectonophysics, 29, 293-300, https://doi.org/10.1016/00401951(75)90154-7, 1975.

Schildgen, T. F., van der Beek, P. A., Sinclair, H. D., and Thiede, R. C.: Spatial correlation bias in late-Cenozoic erosion histories derived from thermochronology, Nature, 559, 89-93, https://doi.org/10.1038/s41586-018-0260-6, 2018.

Schlunegger, F. and Kissling, E.: Slab rollback orogeny in the Alps and evolution of the Swiss Molasse basin, Nat. Commun., 6, 8605, https://doi.org/10.1038/ncomms9605, 2015.

Schlunegger, F., Matter, A., and Mange, M. A.: Alluvial-Fan Sedimentation and Structure of the Southern Molasse Basin Margin, Lake Thun Area, Switzerland, Eclogae Geol. Helv., 86, 717-750, 1993.

Schlunegger, F., Burbank, D. W., Matter, A., Engesser, B., and Mödden, C.: Magnetostratigraphic calibration of the Oligocence to Middle Miocene (30-15 Ma) mammal biozones and depositional sequences of the Swiss Molasse Basin, Eclogae Geol. Helv., 89, 753-788, 1996.

Schlunegger, F., Slingerland, R., and Matter, A.: Crustal thickening and crustal extension as controls on the evolution of the drainage network of the central Swiss Alps between $30 \mathrm{Ma}$ and the present: Constraints from the stratigraphy of the North Alpine Foreland Basin and the structural evolution of the, Basin Res., 10, 197-212, https://doi.org/10.1046/j.1365-2117.1998.00063.x, 1998.

Schmid, S. M., Pfiffner, O. A., Froitzheim, N., Schönborn, G., and Kissling, E.: Geophysical-geological transect and tectonic evolution of the Swiss-Italian Alps, Tectonics, 15, 1036-1064, https://doi.org/10.1029/96TC00433, 1996.

Schmid, S. M., Fügenschuh, B., Kissling, E., and Schuster, R.: Tectonic map and overall architecture of the Alpine orogen, Eclogae Geol. Helv., 97, 93-117, https://doi.org/10.1007/s00015004-1113-x, 2004.

Sinclair, H. D.: Flysch to molasse transition in peripheral foreland basins: The role of the passive margin versus slab breakoff, Geology, 25, 1123-1126, 1997.

Sinclair, H. D., Coakley, B. J., Allen, P. A., and Watts, A. B.: Simulation of foreland basin stratigraphy using a diffusion model of mountain belt uplift and erosion: An example from the Central Alps, Switzerland, Tectonics, 10, 599-620, 1991.

Spear, F. S.: Metamorphic Phase Equilibria And PresureTemperature-Time-Paths (2nd ed.), Mineralogical Society of America monograph, USA, 1994.
Spiegel, C., Kuhlemann, J., Dunkl, I., Frisch, W., Von Eynatten, H., and Balogh, K.: The erosion history of the Central Alps: Evidence from zircon fission track data of the foreland basin sediments, Terra Nova, 12, 163-170, https://doi.org/10.1046/j.13653121.2000.00289.x, 2000.

Spiegel, C., Siebel, W., Frisch, W., and Berner, Z.: Nd and Sr isotopic ratios and trace element geochemistry of epidote from the Swiss Molasse Basin as provenance indicators: Implications for the reconstruction of the exhumation history of the Central Alps, Chem. Geol., 189, 231-250, https://doi.org/10.1016/S00092541(02)00132-8, 2002.

Spillmann, P.: Die Geologie des Grenzbereichs im penninischostalpinen südlichen Berninagebirge, Ph.D. thesis, ETH Zürich, Switzerland, 262 pp., 1993.

Spillmann, P. and Büchi, H.: The Pre-Alpine Basement of the Lower Austro-Alpine Nappes in ther Bernina Massif (Grisons, Switzerland; Valtellina, Italy), in: The Pre-Mesozoic Geology in the Alps, edited by: von Raumer, J. F. and Neubauer, F., Springer Berlin Heidelberg, Germany, 457-467, 1993.

Steck, A. and Burri, G.: Chemismus und Paragenesen von Granaten aus Granitgneisen der Grünschiefer- und Amphibolitfazies der Zentralalpen, Schweiz. Miner. Petrog., 51, 534-538, 1971.

Stutenbecker, L.: Detrital garnet chemistry from the Molasse basin (supplementary data), https://doi.org/10.6084/m9.figshare.8269742.v1, 2019.

Stutenbecker, L., Berger, A., and Schlunegger, F.: The potential of detrital garnet as a provenance proxy in the Central Swiss Alps, Sedimentary Geol., 351, 11-20, https://doi.org/10.1016/j.sedgeo.2017.02.002, 2017.

Stutenbecker, L., Delunel, R., Schlunegger, F., Silva, T. A., Šegvić, B., Girardclos, S., Bakker, M., Costa, A., Lane, S. N., Loizeau, J.L., Molnar, P., Akçar, N., and Christl, M.: Reduced sediment supply in a fast eroding landscape? A multi-proxy sediment budget of the upper Rhône basin, Central Alps, Sedimentary Geol., 375, 105-119, https://doi.org/10.1016/j.sedgeo.2017.12.013, 2018.

Thélin, P., Sartori, M., Lengeler, R., and Schaerer, J.-P.: Eclogites of Paleozoic or early Alpine age in the basement of the Penninic Siviez-Mischabel nappe, Wallis, Switzerland, Lithos, 25, 71-88, 1990.

Tolosana-Delgado, R., von Eynatten, H., Krippner, A., and Meinhold, G.: A multivariate discrimination scheme of detrital garnet chemistry for use in sedimentary provenance analysis, Sedimentary Geol., 375, 14-26, https://doi.org/10.1016/j.sedgeo.2017.11.003, 2018.

Trümpy, R.: Geology of Switzerland. A guide book, Part A: An outline of the geology of Switzerland, Basel, Switzerland: Wepf, 1980.

von Raumer, J. F., Abrecht, J., Bussy, F., Lombardo, B., Menot, R.P., and Schaltegger, U.: The Palaeozoic metamorphic evolution of the Alpine External Massifs, Schweiz. Miner. Petrog., 79, 522, 1999.

Vernon, A. J., van der Beek, P. A., Sinclair, H. D., and Rahn, M. K.: Increase in late Neogene denudation of the European Alps confirmed by analysis of a fission-track thermochronology database, Earth Planet. Sc. Lett., 270, 316-329, https://doi.org/10.1016/j.epsl.2008.03.053, 2008.

Vernon, A. J., van der Beek, P. A., and Sinclair, H. D.: Spatial correlation between long-term exhumation rates and presentday forc- 
ing parameters in the western European Alps, Geology, 37, 859862, https://doi.org/10.1130/G25740A.1, 2009.

von Eynatten, H.: Petrography and chemistry of sandstones from the Swiss Molasse Basin: An archive of the Oligocene to Miocene evolution of the Central Alps, Sedimentology, 50, 703-724, https://doi.org/10.1046/j.1365-3091.2003.00571.x, 2003.

von Eynatten, H. and Wijbrans, J. R.: Precise tracing of exhumation and provenance using ${ }^{40} \mathrm{Ar} /{ }^{39} \mathrm{Ar}$ geochronology of detrital white mica?: the example of the Central Alps, Geol. Soc. Spec. Publ., 208, 289-305, 2003.

Wagner, G. A., Reimer, G. M., and Jäger, E.: Cooling ages derived by apatite fission track, mica $\mathrm{Rb}-\mathrm{Sr}$ and $\mathrm{K}-\mathrm{Ar}$ dating: The uplift and cooling history of the central Alps, Memorie degli Istituti di Geologia e Mineralogia dell' Universita di Padova, 30, 1-27, 1977.

Weber, S. and Bucher, K.: An eclogite-bearing continental tectonic slice in the Zermatt-Saas high-pressure ophiolites at Trockener Steg (Zermatt, Swiss Western Alps), Lithos, 232, 336-359, https://doi.org/10.1016/j.lithos.2015.07.010, 2015.
Wildi, W.: Heavy mineral distribution and dispersal pattern in penninic and ligurian flysch basins (Alps, northern Appennines), Giorn. Geol., 47, 77-99, 1985.

Winkler, W.: The tecto-metamorphic evolution of the Cretaceous northern Adriatic margin as recorded by sedimentary series (western part of the Eastern Alps), Eclogae Geol. Helv., 89, 527$551,1996$.

Wittmann, H., von Blanckenburg, F., Kruesmann, T., Norton, K. P., and Kubik, P. W.: Relation between rock uplift and denudation from cosmogenic nuclides in river sediment in the Central Alps of Switzerland, J. Geophys. Res.-Earth, 112, F04010, https://doi.org/10.1029/2006JF000729, 2007. 